\title{
Antioxidant and Antibacterial Activity from Three Different Solvents of Nephelium ramboutan-ake Leaves Crude Extract
}

\author{
Agmi Sinta Putri ${ }^{1}$ Whicliffe Fiernaleonardo Pasedan ${ }^{1}$ Irawan Wijaya Kusuma ${ }^{1}$ \\ Harlinda Kuspradini ${ }^{1 *}$ \\ ${ }^{1}$ Faculty of Forestry Mulawarman University Samarinda, East Kalimantan, Indonesia \\ "Corresponding author. Email: hkuspradini@fahutan.unmul.ac.id
}

\begin{abstract}
Nephelium ramboutan-ake, is a species of Sapindaceae family, locally named Maritam from Kalimantan. However, there is limited information about the potency of this plant. The present study's objective was to carry out the antioxidant and antibacterial activity of $N$. ramboutan-ake leaf extract by three different solvents of extraction. The extracts obtained by successive solvent extraction from the maceration method use n-hexane, ethyl acetate, and ethanol solvent. Antioxidant activity was analyzed by DPPH radical scavenging assay compared to ascorbic acid. Antibacterial activity was assayed using the 96 well-plate microdilution broth method against Streptococcus mutans and $S$. sobrinus compared with chloramphenicol as a positive control. This research showed that ethanol extract was the highest yield, followed by ethyl acetate and n-hexane extract. All extracts potentially scavenged DPPH free radicals at a concentration of 25,50 , and $100 \mathrm{ppm}$. These plant extracts also could inhibit all tested microorganisms. $N$. ramboutan-ake can be used as a source of natural medicinal material.
\end{abstract}

Keywords: Antioxidant, Antibacterial, Nephelium ramboutan-ake, Leaf extract

\section{INTRODUCTION}

The genus Nephelium (family Sapindaceae) is one of the four genera of native fruits cultivated in Indonesia. $N$. ramboutan-ake has been widely known as rambutan ake, maritam, rambutan babat, rambutan sebabat, tenggaring, pulasan, kapulasan, tukoubiawak, molaitomo, and mulitan [1-3]. This plant was distributed in India, Indonesia, Malaysia, Myanmar, and the Philippines. $N$. ramboutan-ake is a tree to $24 \mathrm{~m}$ tall, trunk $45 \mathrm{~cm}$ in diameter, buttresses up to $1.5 \mathrm{~m}$ tall. $N$. ramboutan-ake is a variable species and may closely resemble $N$. lapaceum [4].

Several biological activities of Nephelium fruit (peel and seed) are reported, such as antioxidant, antibacterial, anti-inflammation, hypoglycaemic, antidiabetic, and anticancer. $N$. ramboutan-ake also has bioactivity such as cytotoxicity, anticancer and antioxidant activities [5,6]. Traditionally, the decoction of $N$. ramboutan-ake root is used for treating feverish patients [5]. Therefore, this work aims to evaluate $\mathrm{N}$. ramboutan-ake leaf's bioactivities such as antibacterial activity against Streptococcus mutans, S. Sobrinus, E. coli, P. acnes, the antioxidant activity using DPPH radicals, and to correlate with chemical components by phytochemical screening.

\section{MATERIAL AND METHODS}

\subsection{Sample Collection}

The raw material was the maritam ( $N$. ramboutanake) plant found in Lempake village, South Samarinda sub-district. This plant was identified by the Laboratory of Plant Physiology, Development, and Tissue Culture, Faculty of Mathematics and Natural Sciences, Mulawarman University, Samarinda, Indonesia. The leaf part used as a sample was air-dried and prepared for the extraction process. 


\subsection{Extraction by Successive Maceration}

$189 \mathrm{~g}$ of powdered samples were soaked with $n$ hexane, ethyl acetate, and $96 \%$ ethanol solvents using successive maceration method in a mechanical shaker at room temperature for two days [7]. The solid filtered and evaporated using a rotary vacuum evaporator at 40 ${ }^{\circ} \mathrm{C}$ to obtain each solvent's crude extract. The result of extraction reported as percents yield $(\%)=$ (weight of extract in grams/weight of sample in grams) x 100 [8].

\subsection{Phytochemical Analysis}

Phytochemical analyses were performed using the standard procedures described by Kokate [9], Senthilmurugan [10], Harborne [11]. The phytochemical constituents included alkaloids, flavonoids, terpenoids, tannins, saponins, steroids, carotenoids, and coumarins were tested in this study.

\subsection{Antioxidant Assay}

The radical DPPH was used to evaluate the free radical scavenging activity of the crude extracts and standard vitamin C, modified by the method of [12]. All successive extracts, 100, 50, and $25 \mathrm{ppm}$, were used as the final concentration in dimethyl sulphoxide. After incubation (20 minutes), all samples' antioxidant activity was determined by the absorbances measured spectrophotometrically at $514 \mathrm{~nm}$ and presented in percentage of free radical DPPH inhibition.

\subsection{Antibacterial Assay}

Different crude extracts were tested for their antibacterial properties using the broth microdilution method in 96-well microplates. The antibacterial activity of samples was assessed for the Minimum Inhibitory Concentration (MIC) and the Minimum Bactericidal Concentration described by Kuspradini et al. [7]. Three concentrations used in this study were 1250,625 , and $312.5 \mu \mathrm{g} / \mathrm{ml}$ diluted in $40 \%$ ethanol and chloramphenicol used as a positive control. The test was repeated in triplicate for each sample.

\section{RESULT AND DISCUSSIONS}

The result of extraction and phytochemical analysis is given in Table 1. The ethanol extract has the highest yield while the $n$-hexane was the lowest. Phytochemical screening of the plant showed the presence of alkaloids, tannins, and coumarins in all extracts. Simultaneously, flavonoids were absent from n-hexane extract, and terpenoids did not contain ethyl acetate extract. Saponins were only present in ethanol extract, while steroids also only present in ethyl acetate extract.

Table 1. Yield And Phytochemical Profiles Of Nephelium Ramboutan-Ake Leaf Extracts

\begin{tabular}{lccc}
\hline & \multicolumn{3}{c}{ Extracts } \\
\cline { 2 - 4 } Parameters & $\boldsymbol{n}$-hexane & $\begin{array}{c}\text { Ethyl } \\
\text { acetate }\end{array}$ & Ethanol \\
\hline Yields (\%) & 0.45 & 3.08 & 6.84 \\
Alkaloids & + & + & + \\
Flavonoids & - & + & + \\
Terpenoids & + & - & + \\
Tannins & + & + & + \\
Saponins & - & - & + \\
Steroids & - & + & - \\
Carotenoids & - & - & - \\
Coumarins & + & + & + \\
\hline
\end{tabular}

The ethanol solvent is usually used in maceration because nonpolar, semi-polar, and polar compounds are easily diluted in this solvent [13]. It could be the reason ethanol extract has the highest yield than others. According to Javanmardi et al. [14] and Rohman et al. [15], the presence of phenolics, flavonoids, and carotenoids are found in N. lappaceum. Carbohydrates, alkaloids, steroids, glycosides, triterpenoids, and tannins also present in $N$. lappaceum epicarp methanolic extract [16].

Antibacterial activity of leaf extracts was done by microdilution method, and the result was given in Table 2. All extracts showed strong antibacterial activity, with the MIC values were $312.5 \mu \mathrm{g} / \mathrm{ml}$ for all extracts and tested bacteria. This inhibitory activity was as strong as the synthetic standard (chloramphenicol); however, different with their MBC values $(>1250 \mu \mathrm{g} / \mathrm{ml})$ showed that all samples did not have bactericidal properties.

Table 2. The Antibacterial Activity (MIC and MBC Values) of Nephelium ramboutan-ake Leaf Extracts

\begin{tabular}{lcccc}
\hline \multirow{2}{*}{ Sample } & \multicolumn{4}{c}{ MIC $(\boldsymbol{\mu g} / \mathbf{m l})$} \\
\cline { 2 - 5 } & S. mutans & S. sobrinus & E. coli & P. acnes \\
\hline n-Hexane & 312.5 & 312.5 & 312.5 & 312.5 \\
Ethyl acetate & 312.5 & 312.5 & 312.5 & 312.5 \\
Ethanol & 312.5 & 312.5 & 312.5 & 312.5 \\
Chloramphenicol & 312.5 & 312.5 & 312.5 & 312.5 \\
\hline \multicolumn{5}{c}{ MBC $(\mu \mathrm{g} / \mathrm{ml})$} \\
\hline Sample & S. mutans & S. sobrinus & E. coli & P. acnes \\
$n$-Hexane & $>1250$ & $>1250$ & $>1250$ & $>1250$ \\
Ethyl acetate & $>1250$ & $>1250$ & $>1250$ & $>1250$ \\
Ethanol & $>1250$ & $>1250$ & $>1250$ & $>1250$ \\
Chloramphenicol & 312.5 & 312.5 & 312.5 & 312.5 \\
\hline
\end{tabular}


In this study, the N. ramboutan-ake leaf extracts have a moderate antibacterial activity (MIC) against all tested bacterias. The classification of bacterial inhibition was explained by Salni et al. [17]. Fatisa [18] reported that crude extract of bark and seed from $N$. ramboutanake have a weak MIC and substantial MBC value against Staphylococcus aureus, respectively. $N$. lapaceum which is one genus of the tested plant contained phenolic compounds, the groups of flavonoid as antioxidant and antibacterial. The study that was conducted by Sulistiyaningsih et al. [19] and Bhat and Al-daihan [20] showed that the ethanolic extract of $N$. lappaceum leaf has antibacterial activity against Pseudomonas aeruginosa and Staphylococcus aureus.

The radical scavenging activity of $N$. ramboutan-ake leaf and the standard antioxidant vitamin $\mathrm{C}$ has been done by DPPH method with increasing concentrations from 25-100 ppm. The result as shown in Figure 1, all extracts were scavenged the DPPH radical with range of $37.42-81.64 \%$. The ethanol extract showed very good activity in concentration of $25 \mathrm{ppm}$ which almost approached the ability of vitamin C.

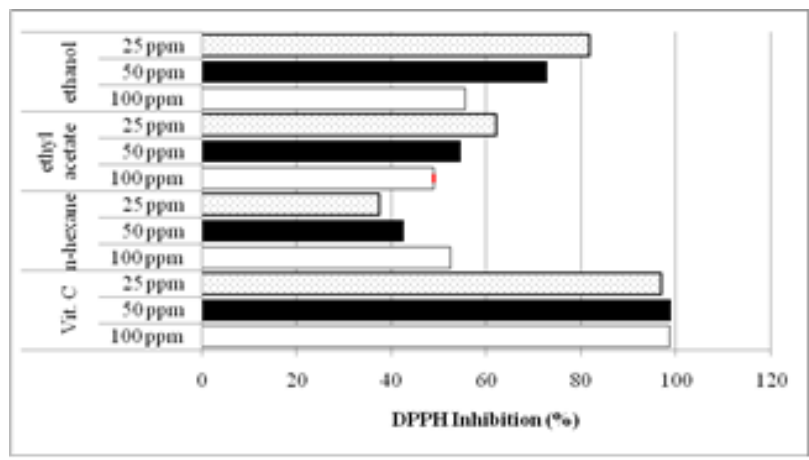

Figure 1 Antioxidant activity of $N$. ramboutan-ake leaf extracts against DPPH free radical

Ling et al. [21] investigated that several parts of $N$. lappaceum and $N$. ramboutan-ake plants commonly contained phenolic compounds with cytotoxicity and potential as a natural antioxidant. The hexane, ethyl acetate, and ethanol extracts of N.lappaceum leaves from five cultivars also have similar antiradical scavenging activity toward DPPH radical as reported by Fidrianny et al. [22]. The research of Mistriyani et al. [23] mentioned that Rambutan ( $N$. lappaceum) peel methanolic extracts and their fractions from two cultivars (Aceh and Binjai) showed powerful antioxidant activity against several radicals and correlated with high amounts of phenolics and flavonoid contents. From the primary phytochemical screening, it has been determined that the antioxidant effect of plant products is mainly due to the radical scavenging activity of flavonoids, polyphenols, and tannins [24].

\section{CONCLUSIONS}

The present study's result suggests that the leaf of $N$. ramboutan-ake could inhibit the tested radical and bacterias very well. It was concluded that this plant potentially due for further application in the pharmaceutical industry.

\section{ACKNOWLEDGMENTS}

The authors would like to thank the members of the forest product chemistry laboratory.

\section{REFERENCES}

[1] T. Uji, Review. Biodiversity of native fruits in Indonesia and their potential, Biodiversitas 8 (2007) 157-167.

[2] K.C. Wong, S.N. Wong, H.K. Loi, C.L. Lim, Volatile constituents from the fruits of four edible Sapindaceae: rambutan (Nephelium lappaceum L.), pulasan (N. ramboutan-ake) (Labil.) Leenh.), longan (Dimocarpus longan Lour.), and mata kucing (D. Longan ssp. Malesianus Leenh.), Flavour and Fragrance J. 11 (1998) 223-229.

[3] Koesrini, Mawardi, Sardjijo, A. Susilawati, Normahani, Conservation of excotice fruit plants in Swampland, The report of Research, BalitraBanjarbaru, 2005, pp. 20. [Indonesian]

[4] C. Orwa, A. Mutua, R. Kindt, R. Jamnadass, S. Anthony, Agroforestree Database: a tree reference and selection guide version 4.0, 2009. Available at http://www.worldagroforestry.org/sites/treedbs/tre edatabases.asp

[5] C.K. Chan, B.H. Goh, M.N.A. Kamarudin, H.A. Kadir, Aqueous fraction of Nephelium ramboutanake Rind induces mitochondrial-mediated apoptosis in HT-29 human colorectal adenocarcinoma cells, Molecules 17 (2012) 6633 6657.

[6] Sukemi, K. Khownium, E.T. Arung, I.W. Kusuma, W. Mingvanish, Antioxidant activities of crude methanolic extract of Nephelium ramboutan-ake (Labill.) Leenh. Peel. Pure and Applied Chemistry International Conference (PACCON), 2015, pp. 123-127.

[7] H. Kuspradini, I. Wulandari, A.S. Putri, S.Y. Tiya, I.W. Kusuma, Phytochemical, antioxidant and antimicrobial properties of Litsea angulata extracts, F1000 Research 7 (2018) 1839.

[8] E. Abdel-Aal, A.M. Haroon, J. Mofeed, Successive solvent extraction and GC-MS analysis for the evaluation of the phytochemical 
constituents of the filamentous green alga Spirogyra longata, The Egyptian Journal of Aquatic Research 41(3) (2015) 233-246.

[9] C.K. Kokate, Pharmacognosy 16th Edn, Niali Prakasham, Mumbai India, 2001.

[10] G.B. Senthilmurugan, B. Vasanthe, K. Suresh, Screening and antibacterial activity analysis of some important medicinal plants, International Journal of Innovation and Applied Studies 2(2) (2013) 146-152.

[11] J.B. Harborne, Phytochemical method: modern method guidelines of plants analysis, ITB, Bandung, 1987. [Indonesia]

[12] H. Kuspradini, A.M. Rosiarto, A.S. Putri, I.W. Kusuma, Antioxidant and toxicity properties of anthocyanin extracted from red flower of four tropical shrubs, Nusantara Bioscience 8(2) (2016) 135-140.

[13] Arifin, Helmi, Aggraini, Nelvi, Handayani, Dian, Rasyid, Roslinda, Standarization of Eugenia Cumini Merr. Leaf ethanolic extract, J. Science Tech. Pharm. 11(2) (2006).

[14] J. Javanmardi, C. Stushnoff, E. Locke, J.M. Vivanco, Antioxidant activity and total phenolic content of Iranian Ocimum accessions, Food Chem. 83 (2003) 547-550.

[15] A. Rohman, S. Riyanto, D. Utari, Antioxidant activities, total phenolic and flavonoid contents of ethyl acetate extract of Mengkudu (Morinda citrifolia L.) fruit and its fractions, Indonesian J. Pharm. 17 (2006) 136-142.

[16] R. Nethaji, G. Thooyavan, N.K. Mullai, K. Ashok, Phytochemical profiling, antioxidant and antimicrobial activity of methanol extract in rambutan fruit (Nephelium lappaceum) epicarp against the human pathogens, International Journal of Current Innovation Research 1(9) (2015) 201206.

[17] Salni, H. Marisa, R.W. Mukti, Isolation of antibacterial compounds from the leaves of jengkol (Pithecolobium lobatum Benth) and thier MIC values, Journal of Science Research 14(1) (2011). [Indonesian]

[18] Y. Fatisa, Antibacterial activity of Pulasan (Nephelium mutalibe) fruit, peel and seed extracts against Staphylococcus aureus and Escherichia coli in vitro, Journal of Animal Husbandry 10(1) (2013) 31-38. [Indonesian]

[19] S. Sulistiyaningsih, M.S. Nabila, I.A. Wicaksono, A. Budiman. Antibacterial activity of ethanol extract and fraction of Ramboutan leaf (Nephelium lappaceum) against Pseudomonas aeruginosa multiresistant, National Journal of Physiology, Pharmacy and Pharmacology 18(2) (2018) $257-$ 261.

[20] R.S. Bhat, S. Al-daihan, Antimicrobial activity of Litchi chinensis and Nephelium lappaceum aqueous seed extracts against some pathogenic bacterial strains, Journal of King Saud UniversityScience 26(1) (2014) 79-82. DOI: https://doi.org/10.1016/j.jksus.2013.05.007

[21] L.T. Ling, K.R. Ammu, S. Thavamanithevi, M.C.H. wee dan D.P. Uma, Assessment of antioxidant capacity and cytotoxicity of selected malaysian plants, J. Molecules. 15 (2010) 21392151.

[22] I. Fidrianny, P.I. Sari, K.R. Wirasutisna, Antioxidant activities in various peel extracts of four varieties rambutan (Nephelium lappaceum) using DPPH, FRAP assays, Int. J. Pharmacog. Res. 7 (2015) 280-285.

[23] Mistriyani, S. Riyanto, A. Rohman, Antioxidant activities of Ramboutan (Nephelium lappaceum L) peel in vitro, Food Research 2(1) (2018) 119-123.

[24] R. Scherer, H.T. Goday, Antioxidant activity index (AAI) by the 2-diphenyl-1-picrylhydrazyl method, Food Chemistry 112 (2009) 654-658. 